\title{
PRODUKSI DAN KARAKTERISASI ENZIM PEKTINASE BAKTERI PEKTINOLITIK DARI LIMBAH KULIT JERUK UNTUK KLARIFIKASI JUS LEMON (Citrus limon)
}

\author{
PRODUCTION AND CHARACTERIZATION PECTINASE ENZYME PECTINOLITIC \\ BACTERIA FROM CITRUS PEEL WASTED FOR LEMON JUICE (Citrus Limon) \\ CLARIFICATION
}

\author{
Esti Widowati, Rohula Utami, Edhi Nurhartadi, M.A.M Andriani, Ririn Hanifah \\ Program Studi Ilmu dan Teknologi Pangan Fakultas Pertanian Universitas Sebelas Maret \\ Email: esti_widowati@yahoo.com
}

\begin{abstract}
The aims of this research were to isolate and characterize the pectinolytic bacteria from citrus peel waste, determine the character of the optimum ( $\mathrm{pH}$, temperature, $K_{M}$ and $\left.V_{\max }\right)$ of the pectinase enzyme and determine the effect of the enzyme on the characteristics of lemon juice. Isolation and characterization of the pectinolitic bacteria were the first stage of the research. Isolation, presipitation, dyalisis and determination of the pectinases enzyme characters (optimum $\mathrm{pH}$ and temperature, $K_{m}$ and $V_{\text {maks }}$ ) were the second stage of the research. From ten selected bacterial isolates obtained three isolates that produce enzymes that are best in the lemon juice clarification process that isolates 1, 4 and 9. Selection is based on the value of a low viscosity, the value of a high total dissolved solids and high transmittance value. From the results known that all bacterial isolates were obtained Gram-negative bacteria, negative endospores and positive catalase. Isolates 1, 4 and 9 optimum at $\mathrm{pH}$ 4.0, optimum temperature at 50 $0^{\circ} \mathrm{C}$ stable in the $\mathrm{pH}$ range 3.0-4.0, stable at a temperature of 30$50^{\circ} \mathrm{C} . K_{M}$ value for isolates 1,4 and 9 in succession is $0.022 \mathrm{mg} / \mathrm{ml}, 0.009 \mathrm{mg} / \mathrm{ml}, 0.017 \mathrm{mg} / \mathrm{ml}$, whereas the $V_{\max }$ value in succession is $0.041 \mathrm{U} / \mathrm{ml}, 0,036 \mathrm{U} / \mathrm{ml}, 0,039 \mathrm{U} / \mathrm{ml}$.
\end{abstract}

Keywords : Enzyme, Juice Clarification, Pectin, Pectinases

\section{ABSTRAK}

Penelitian ini bertujuan untuk mengisolasi dan mengkarakterisasi bakteri pektinolitik dari limbah kulit jeruk, mengetahui karakter optimum ( $\mathrm{pH}$, suhu, $\mathrm{K}_{\mathrm{M}}$ dan $\mathrm{V}_{\text {maks }}$ ) dari enzim pektinase dan mengetahui pengaruh penambahan enzim terhadap karakteristik jus lemon. Penelitian tahap pertama yaitu dilakukan untuk mengisolasi dan mengkharakterisasi bakteri pektinolitik. Penelitian tahap kedua dilakukan isolasi, presipitasi, dialisis dan penentuan karakteristik enzim pektinase ( $\mathrm{pH}$ dan suhu optimum, kestabilan $\mathrm{pH}$ dan suhu, $\mathrm{K}_{\mathrm{m}}$ and $\mathrm{V}_{\text {maks }}$ ). Dari sepuluh isolat bakteri dipilih tiga isolat yang menghasilkan enzim yang cocok dalam proses klarifikasi jus lemon yaitu isolat 1, 4 dan 9. Pemilihan ini berdasarkan pada nilai viskositas yang rendah, nilai total padatan terlarut yang tinggi dan nilai transmitansi yang tinggi. Berdasarkan hasil yang diperoleh semua isolat bakteri yang didapatkan termasuk bakteri Gram negatif, endospora negatif dan positif pada uji katalase. . Isolat 1, 4 dan 9 optimum pada $\mathrm{pH} 4,0$, optimum pada suhu $50^{\circ} \mathrm{C}$ stabil pada kisaran $\mathrm{pH} 3,0-4,0$ stabil pada suhu $30-50^{\circ} \mathrm{C}$. Nilai $\mathrm{K}_{\mathrm{M}}$ isolat 1, 4 dan 9 berturut-turut yaitu $0,022 \mathrm{mg} / \mathrm{ml} ; 0,009 \mathrm{mg} / \mathrm{ml} ; 0,017 \mathrm{mg} / \mathrm{ml}$, sedangkan nilai $\mathrm{V}_{\text {maks }}$ berturutturut yaitu $0,041 \mathrm{U} / \mathrm{ml} ; 0,036 \mathrm{U} / \mathrm{ml} ; 0,039 \mathrm{U} / \mathrm{ml}$.

Kata kunci : Pektin, Enzim Pektinase, Klarifikasi Jus

\section{PENDAHULUAN}

Kekeruhan pada produk jus lemon merupakan kendala tersendiri bagi produsen jus buah dalam menciptakan jus yang jernih, selain kekeruhan masalah lain yaitu jus cepat membentuk jelly. Proses klarifikasi pada jus merupakan salah satu proses untuk mendapatkan jus yang jernih sehingga jus yang dihasilkan tidak akan membentuk gel. Jeruk lemon (Citrus limon) banyak digunakan dalam pembuatan jus atau sering juga digunakan sebagai penambah cita rasa suatu masakan, karena rasanya yang menyegarkan. Kandungan pektin yang tinggi pada jeruk lemon menyebabkan jus yang dihasilkan dari jeruk lemon cepat mengalami kekeruhan dan membentuk jelly.

Pektin adalah substansi alami yang terdapat pada sebagian besar tanaman pangan. Disebutkan dalam Baker (1997) bahwa kadar pektin jeruk lemon berkisar 2,80-2,99\%. Pada industri jus dan konsentrat jus, keberadaan pektin dapat menjadi masalah untuk menghasilkan produksi jus yang jernih. Setiap produsen jus akan melakukan pengujian kandungan pektin, yang kemudian 
akan melakukan depektinasi. Depektinasi sangat penting, terutama untuk jus dalam bentuk konsentrat yang kemudian akan mengalami proses rekonstitusi untuk diminum. Jika tidak dilakukan depektinasi, koloid pektin dapat mengendap pada produk akhir. Jus rekonstitusi akan menjadi keruh dan berkabut atau bahkan berikatan dengan partikel lain membentuk partikel yang lebih besar, jika pektin tetap berada dalam suspensi (Noer, 2008).

Berdasarkan penelitian yang dilakukan oleh Banik dan Ghosh (2008) menunjukkan bahwa pertumbuhan bakteri Bacillus sp dan Streptomyces sp lebih tinggi sehingga enzim yang dihasilkan lebih banyak dibandingkan dengan jamur Aspergilus sp dan Penicillium sp. Selain itu waktu yang dibutuhkan untuk isolasi bakteri pektinolitik lebih cepat dibandingkan dengan isolasi dari jamur. Penelitian ini bertujuan untuk mengisolasi dan mengkarakterisasi enzim pektinase dari limbah kulit jeruk; mengetahui karakter ( $\mathrm{pH}$ optimum, suhu optimum, kestabilan $\mathrm{pH}$ dan suhu, $\mathrm{K}_{\mathrm{M}}, \mathrm{V}_{\text {maks }}$ ) enzim pektinase; mengetahui pengaruh enzim pektinase terhadap kekeruhan, viskositas, dan total padatan terlarut dalam klarifikasi jus Lemon.

\section{METODE PENELITIAN}

\section{Penelitian Tahap I}

Isolasi dan Karakterisasi Bakteri Pektinolitik (Benson, 2002; Hadioetomo, 1990) dan Penentuan Isolat Uji (Ordonez et al., 1998; Modifikasi Arthey and Ashurst, 2001)

Sampel kulit jeruk ditimbang tepat sebanyak 5 g kemudian dihancurkan dengan mortar steril. Seri pengenceran pada $10^{-1}-10^{-6}$ dengan larutan pengencer garam fisiologis $(\mathrm{NaCl}) \quad 0,85 \%$. Media pektin agar (Yeast extract 1,0 g; $\mathrm{Na}_{2} \mathrm{HPO}_{4} 0,9 \mathrm{~g} ; \mathrm{KH}_{2} \mathrm{PO}_{4} 1,0 \mathrm{~g}$; $\mathrm{MgSO}_{4} .7 \mathrm{H}_{2} \mathrm{O} 0,5 \mathrm{~g} ; \mathrm{KCl} \mathrm{0,2} \mathrm{g}$; Pektin Citrus 1,0 g; Bacteriological Agar $15 \mathrm{~g}$ dalam $1 \mathrm{~L}$ ) sebagai media selektif bakteri pektinolitik. Inkubasi dilakukan pada suhu $37^{\circ} \mathrm{C}$ dan $50^{\circ} \mathrm{C}$ selama 24-48 jam. Morfologi koloni bakteri diamati berdasarkan bentuk, tepian, elevasi, struktur dalam, warna dan diameter.
Preservasi isolat dilakukan dalam media pektin agar miring pada suhu $4^{\circ} \mathrm{C}$.

Karakterisasi morfologi sel isolat meliputi pewarnaan Gram, pewarnaan endospora dan pengukuran sel. Uji biokimia dilakukan dengan uji katalase. Seleksi isolat uji dilakukan berdasarkan aktivitas enzim kasar (U/ml), dan klarifikasi jus jeruk (viskositas, \% $\mathrm{T}$ dan total padatan terlarut (TPT)) dan depolimerisasi pektin cair $1 \%$ (viskositas dan \% T).

\section{Penelitian Tahap II}

\section{Produksi, Ekstraksi dan Karakterisasi Enzim Pektinase (Fonseca and Said, 1994; Salvador et al., 2002; Barense dkk, 2001; Ordonez et al, 1998)}

Produksi enzim dilakukan pada fase logaritmik masing-masing isolat bakteri. Kurva pertumbuhan enzim dihitung dengan metode turbidimetri yaitu dengan menentukan nilai absorbansi setiap sampel. Agitasi dilakukan sampai pada fase logaritmik sesuai dengan kurva standar pada kecepatan 144 rpm sesuai dengan suhu masing-masing isolat. Aktivitas enzim dianalisis dengan metode DNS. Kurva pertumbuhan isolat dan kurva aktivitas enzim kemudian digabungkan untuk mengetahui hubungan antara jumlah sel dengan aktivitas enzim.

Ekstraksi dilakukan dengan sentrifugasi pada kecepatan $6000 \mathrm{rpm}$ pada suhu $4^{\circ} \mathrm{C}$ selama 15 menit pada kultur isolat pada fase logaritmik. Presipitasi supernatan menggunakan fraksinasi ammonium sulfat 10\%-90\%. Sentrifugasi dilakukan pada kecepatan $12.000 \mathrm{rpm}$ suhu $4^{\circ} \mathrm{C}$ selama 10 menit. Uji aktivitas enzim dilakukan pada fase supernatan dengan metode DNS.

Fraksi kejenuhan dengan aktivitas enzim tertinggi didialisis dengan cara memasukkan enzim kedalam kantung membran selofan. Membran selofan direndam selama 24 jam dengan magnetig stirer pada suhu $4{ }^{\circ} \mathrm{C}$ dalam gelas beaker yang telah diisi dengan buffer asetat $0,05 \mathrm{M} \mathrm{pH}$ 5,2 . 
Karakterisasi enzim pektinase (Ordonez et al., 1998; Barense et al., 2001)

Metode DNS yang digunakan yaitu enzim sebanyak $0,1 \mathrm{ml}$ dicampur dengan 0,9 ml media pereaksi (campuran $0,7 \%$ pektim. citrus dan buffer sodium asetat $0,025 \mathrm{M} \mathrm{pH}$ $4,8)$ kemudian diinkubasi pada suhu $37^{\circ} \mathrm{C}$ selama 30 menit. Selanjutnya sampel ditambahkan $1 \mathrm{ml}$ larutan DNS dan dipanaskan pada suhu $90^{\circ} \mathrm{C}$ selama 10 menit.setelah dingin sampel ditambahkan dengan $0,5 \mathrm{ml}$ K-Na-Tartrat $40 \%$ dan dihomogenkan. Setelah itu sampel ditera absorbansinya pada panjang gelombang 540 nm. Aktivitas enzim ditentukan dengan mengkonversikan nilai absorbansi asam Dgalakturonat dengan persamaan regresi linier kurva standar asam D-galakturonat 100 ppm.

1. $\mathrm{pH}$ Optimum Enzim

0,1 $\mathrm{ml}$ enzim dan ditambahkan dengan $0,9 \mathrm{ml}$ media pereaksi $(0,7 \%(\mathrm{w} / \mathrm{v})$ pektin citrus dan larutan buffer sodium asetat 0,025 M) dengan menggunakan kisaran $\mathrm{pH} 4,0 ; 4,5$; 5,$0 ; 5,5$ dan 6,0 . Selanjutnya larutan diinkubasi pada suhu $37^{\circ} \mathrm{C}$ selama 30 menit. Sampel dianalisis dengan metode DNS.

2. Suhu Optimum Enzim

$0,1 \mathrm{ml}$ enzim dan ditambahkan dengan $0,9 \mathrm{ml}$ media pereaksi $(0,7 \%(\mathrm{w} / \mathrm{v})$ pektin citrus dan larutan buffer sodium asetat 0,025 $\mathrm{M} \mathrm{pH} \mathrm{4,8)} \mathrm{pada} \mathrm{kisaran} \mathrm{suhu} \mathrm{inkubasi} \mathrm{35;} \mathrm{45;}$ 50; 55 dan $60^{\circ} \mathrm{C}$ selama 30 menit. Sampel dianalisis dengan metode DNS.

3. [S], nilai $K_{M}$ dan $V_{\text {maks }}$

$0,1 \mathrm{ml}$ enzim dan ditambahkan dengan $0,9 \mathrm{ml}$ media pereaksi $(0,7 \%(\mathrm{w} / \mathrm{v})$ pektin citrus, [S] sesuai perlakuan yaitu 0,$05 ; 0,1$; 0,$2 ; 0,4$ dan $0,8 \mathrm{mg} / \mathrm{ml}$ dan larutan buffer

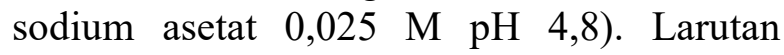
diinkubasi pada suhu $37^{\circ} \mathrm{C}$ selama 30 menit. Sampel dianalisis dengan metode DNS.

Nilai $\mathrm{K}_{\mathrm{M}}$ dan $\mathrm{V}_{\text {maks }}$ ditentukan dengan kurva $1 /[\mathrm{S}]$ terhadap 1/aktivitas enzim sehingga diperoleh garis linier dengan hubungan

$$
1 / \mathrm{v}=1 / \mathrm{V}_{\text {maks }}+\mathrm{K}_{\mathrm{M}} / \mathrm{V}_{\text {maks. }} 1 /[\mathrm{S}]
$$

atau $\mathrm{y}=\mathrm{a}+\mathrm{bx}$

dengan $\mathrm{Y}=1 /$ aktivitas enzim atau $1 /$ kecepatan enzim $(1 / \mathrm{v})$ $\mathrm{X}=1 /$ konsentrasi substrat $(1 /[\mathrm{S}])$
Sehingga untuk menentukan $\mathrm{V}_{\text {maks }}$ dan $\mathrm{K}_{\mathrm{M}}(1 / 2$ $\mathrm{V}_{\text {maks }}$ ) adalah

$$
\begin{aligned}
& \mathrm{a}=1 / \mathrm{V}_{\text {maks }} \text { maka } \mathrm{V}_{\text {maks }}=1 / \mathrm{a} \\
& \mathrm{b}=\mathrm{K}_{\mathrm{M}} / \mathrm{V}_{\text {maks }} \text { maka } \mathrm{K}_{\mathrm{M}}=\mathrm{b} \cdot \mathrm{V}_{\text {maks }}
\end{aligned}
$$

\section{Kestabilan Enzim}

Enzim sebanyak $0,1 \mathrm{ml}$ diinkubasi dalam $0,1 \mathrm{ml}$ buffer sodium asetat $0,025 \mathrm{M}$ pH 3,4,5,6,7,8,9 dan 10 selama 30 menit pada suhu $50^{\circ} \mathrm{C}$. Kestabilan suhu enzim dilakukan dengan enzim sebanyak $0,1 \mathrm{ml}$ diinkubasi dalam $0,1 \mathrm{ml}$ buffer sodium asetat $0,025 \mathrm{M}$ $\mathrm{pH} 7,0$ selama 30 menit pada suhu $30,40,50,60,70,80,90$ dan $100^{\circ} \mathrm{C}$. Aktivitas enzim dianalisis dengan metode DNS.

\section{Analisis data}

Karakter morfologi koloni dan sel bakteri dianalisis secara kualitatif. Kurva standar asam galakturonat, kurva standar isolat, aktivitas enzim pektin hidrolase ekstraseluler dan konstanta kinetika enzim $\mathrm{K}_{\mathrm{M}}$ dan Vmaks ditentukan dengan regresi linier.

\section{HASIL DAN PEMBAHASAN}

10 isolat bakteri pektinolitik yang diisolasi dari sampel kulit jeruk pontianak dan campuran kulit jeruk pontianak, jeruk manis dan jeruk nipis. 6 sampel didapatkan pada suhu $37^{\circ} \mathrm{C}$ dan 4 sampel pada suhu $50^{\circ} \mathrm{C}$ inkubasi dilakukan selama 24 jam.

Penentuan isolat uji dilakukan dengan dua tahap. Tahap pertama isolat uji ditentukan berdasarkan uji aktivitas enzim kasar dan jumlah sel bakteri yang telah diinkubasi selama 24 jam. Aktivitas enzim mengacu pada kurva standar asam galakturonat. Seleksi tahap kedua dilakukan berdasarkan pada kemampuan enzim kasar terhadap klarifikasi jus lemon dan depolimerasi pektin cair 1\% maka diperoleh isolat 1,4 dan 9. Pemilihan isolat untuk klarifikasi jus lemon berdasarkan pada nilai viskositas yang rendah, tingkat kecerahan yang tinggi dan total padatan terlarut yang tinggi. Isolat 1 dan 4 merupakan isolat yang tumbuh pada suhu $37^{\circ} \mathrm{C}$, sedangkan isolat 9 merupakan isolat bakteri yang tumbuh pada suhu $50^{\circ} \mathrm{C}$. 
Pada fase logaritmik enzim membelah menjadi 2 kali lebih cepat sehingga pada saat fase logaritmik aktivitas enzim akan meningkat. Fase logaritmik isolat 1 dimulai pada jam ke 11 setelah inokulasi. Fase logaritmik Isolat 4 dimulai pada jam ke 10 setelah inokulasi. Fase logaritmik isolat 9 dimulai pada jam ke 10 setelah inokulasi

Presipitasi isolat 1 dengan menggunakan fraksi ammonium sulfat $80 \%$. Presipitasi isolat 4 dengan menggunakan fraksi ammonium sulfat $70 \%$. Presipitasi isolat 9 dengan menggunakan fraksi ammonium sulfat $75 \%$.

Konsentrasi protein enzim ditentukan dengan menggunakan uji biuret dengan menggunakan kurva standar Bovine Serum Albumin (BSA). Konsentrasi enzim isolat 1, 4 dan 9 berturut-turut yaitu $0,23913 \mathrm{mg} / \mathrm{ml}$; $0,108696 \mathrm{mg} / \mathrm{ml} ; 0,086957 \mathrm{mg} / \mathrm{ml}$.

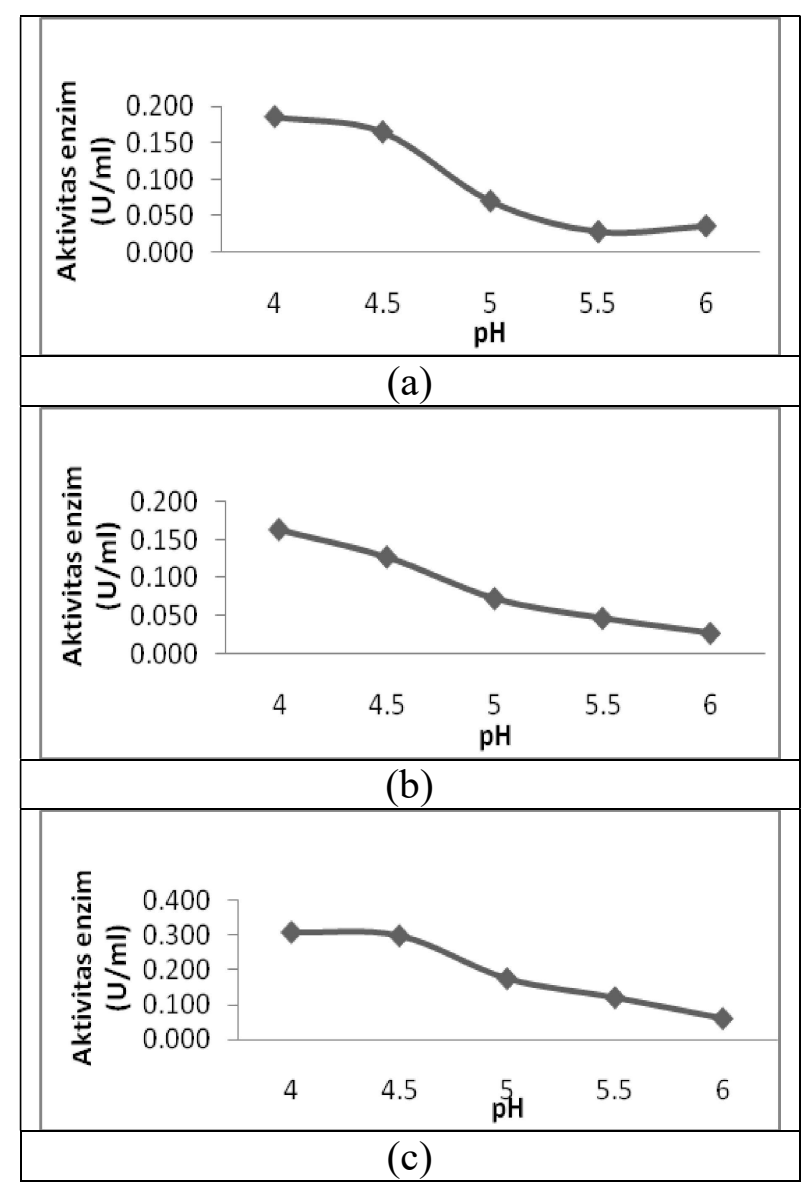

Gambar 1. Hubungan antara $\mathrm{pH}$ dengan Aktivitas Enzim Isolat 1 (a), Isolat 4 (b) dan Isolat 9 (c)

Isolat 1, 4 dan 9 optimum pada $\mathrm{pH} 4,0$ pada suhu inkubasi $50^{\circ} \mathrm{C}$ (Gambar 1). Enzim pektinase memiliki kisaran $\mathrm{pH}$ optimal 3,511(Sieiro et al., 2012). Aktivitas enzim pektinase akan terus menurun seiring dengan semakin tinggi $\mathrm{pH}$. Adanya perubahan muatan ion pada rantai samping residu asam amino enzim yang terlalu besar menyebabkan menurunnya aktivitas spesifik enzim.

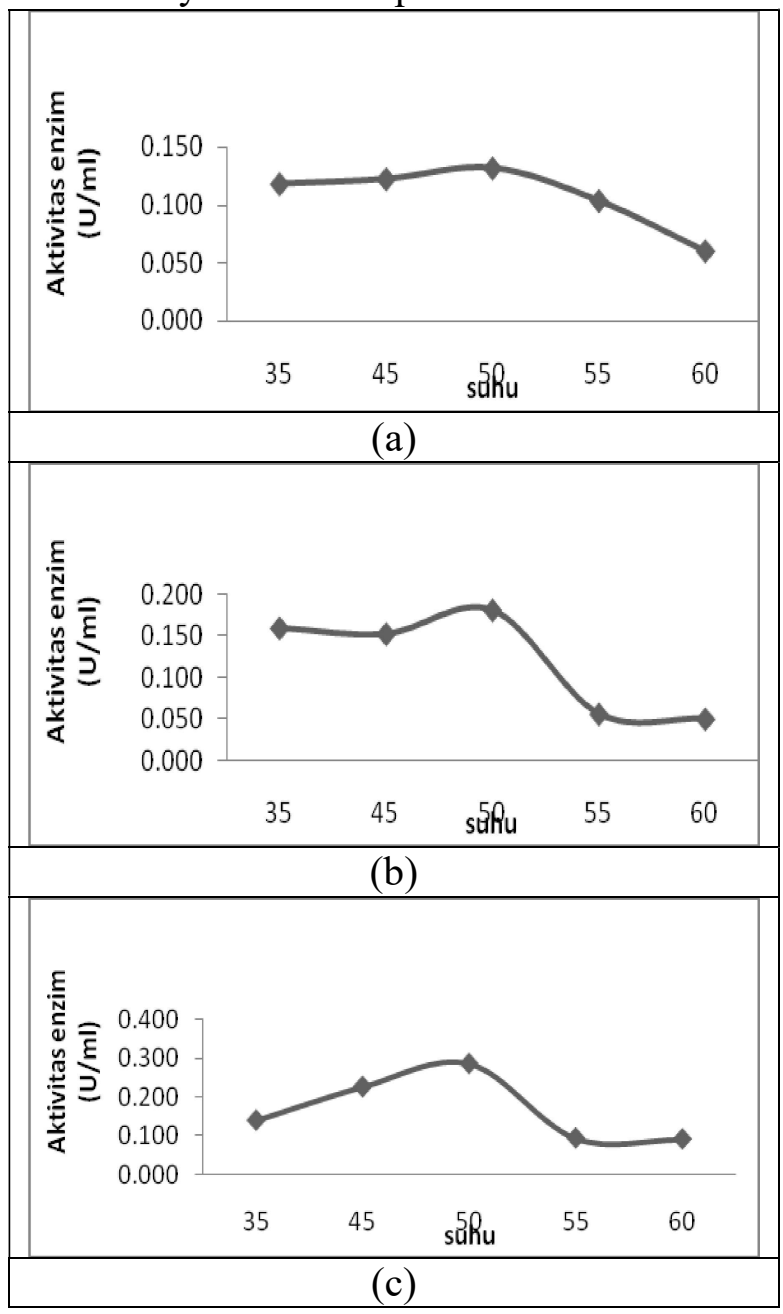

Gambar 2. Hubungan Antara Suhu Dengan Aktivitas Enzim Isolat 1 (a), Isolat 4 (b) dan Isolat 9 (c)

Ketiga isolat enzim optimum pada suhu $50^{\circ} \mathrm{C}$ (Gambar 2). Kisaran suhu optimum enzim pektinase pada suhu $40-75^{\circ} \mathrm{C}$ (Sieiro et al., 2012). Ini menunjukkan bahwa ketiga isolat enzim mampu bekerja optimum pada suhu termofilik yang dapat digunakan pada proses klarifikasi jus. Suhu yang tinggi menyebabkan energi kinetik meningkat sehingga menyebabkan hilangnya struktur primer yang berikatan dengan ikatan kovalen sehingga menurunkan aktivitas enzim.

Pada kisaran $\mathrm{pH}$ 3,0-10 isolat $\mathrm{KJ} 1$, isolat $\mathrm{KJ} 4$ dan isolat $\mathrm{KJ} 9$ stabil pada $\mathrm{pH} 3,0-$ 
5,0 dan inaktif pada $\mathrm{pH} 10$. Dengan stabilnya enzim pada kisaran $\mathrm{pH} 3,0-4,0$ menunjukkan bahwa enzim dapat bekerja pada klarifikasi jus jeruk yang memiliki $\mathrm{pH}$ asam yaitu pada pH 4,0. Ketiga isolat enzim stabil pada suhu $30-50^{\circ} \mathrm{C}$ dan mengalami penurunan pada suhu $60^{\circ} \mathrm{C}$ dan inaktif pada suhu $100^{\circ} \mathrm{C}$. Enzim tersebut juga dapat diaplikasikan dalam klarifikasi jus jeruk skala industri karena stabil pada suhu $30-50^{\circ} \mathrm{C}$. Kestabilan $\mathrm{pH}$ dan suhu enzim dapat menentukan besarnya $\mathrm{pH}$ dan suhu yang akan digunakan dalam produksi enzim dan dalam proses klarifikasi jus.

Salah satu karakteristik enzim yang perlu dipelajari adalah kinetika enzim, berupa parameter $\mathrm{K}_{\mathrm{M}}$ dan $\mathrm{V}_{\text {maks. }}$ Salah satu parameter kinetika enzim yaitu konstanta Michaelis-Menten, yang lebih dikenal dengan $\mathrm{K}_{\mathrm{M}}$. $\mathrm{K}_{\mathrm{M}}$ merupakan konsentrasi substrat yang separuh dari lokasi aktifnya telah terisi, yaitu bila kecepatan reaksi enzim telah mencapai $1 / 2$ $\mathrm{V}_{\text {maks. Nilai }} \mathrm{K}_{\mathrm{M}}$ yang kecil menunjukkan bahwa enzim memiliki afinitas yang tinggi terhadap substrat, dan nilai $K_{M}$ yang besar menunjukkan kebalikannya. Harga $\mathrm{V}$ dari suatu reaksi enzimatis akan meningkat dengan bertambahnya konsentrasi substrat [S], akan tetapi setelah [S] meningkat lebih lanjut akan sampai pada kecepatan yang tetap. Pada konsentrasi enzim tetap (tertentu) harga $\mathrm{V}$ hampir linier dengan [S]. Pada kondisi dimana $\mathrm{V}$ tidak dapat bertambah lagi dengan bertambahnya [S] disebut kecepatan maksimum $\left(\mathrm{V}_{\text {maks }}\right)$. $\mathrm{V}_{\text {maks }}$ merupakan salah satu parameter kinetika enzim (Putra, 2009).

Tabel 1. Nilai $\mathrm{K}_{\mathrm{M}}(\mathrm{mg} / \mathrm{ml})$ dan $\mathrm{V}_{\text {maks }}(\mathrm{U} / \mathrm{ml})$ Enzim Isolat 1, 4 dan 9

\begin{tabular}{ccc}
\hline Isolat & $\mathrm{K}_{\mathrm{M}}(\mathrm{mg} / \mathrm{ml})$ & $\mathrm{V}_{\text {maks }}(\mathrm{U} / \mathrm{ml})$ \\
\hline Isolat 1 & 0,022 & 0,041 \\
Isolat 4 & 0,009 & 0,036 \\
Isolat 9 & 0,017 & 0,039 \\
\hline
\end{tabular}

Berdasarkan Tabel 1, Nilai $\mathrm{K}_{\mathrm{M}}$ dan $\mathrm{V}_{\text {maks }}$ isolat 1 masing-masing yaitu 0,022 $\mathrm{mg} / \mathrm{ml}$ dan $0,041 \mathrm{U} / \mathrm{ml}$. Nilai $\mathrm{K}_{\mathrm{M}}$ dan $\mathrm{V}_{\text {maks }}$ Isolat 4 masing-masing yaitu $0,009 \mathrm{mg} / \mathrm{ml}$ dan $0,036 \mathrm{U} / \mathrm{ml}$. Nilai $\mathrm{K}_{\mathrm{M}}$ dan $\mathrm{V}_{\text {maks }}$ isolat 9 masing-masing yaitu $0,017 \mathrm{mg} / \mathrm{ml}$ dan 0,039
$\mathrm{U} / \mathrm{ml}$. Dari ketiga isolat enzim dapat diketahui bahwa isolat yang memiliki nilai $\mathrm{K}_{\mathrm{M}}$ dan $\mathrm{V}_{\text {maks }}$ yang paling kecil adalah isolat 1. Hal ini menunjukkan bahwa isolat 1 memiliki afinitas terhadap substrat yang paling besar dibandingkan dengan dua enzim isolat lainnya.

\section{KESIMPULAN}

1. Bakteri pektinolitik diisolasi dari limbah kulit jeruk Pontianak dan limbah kulit jeruk campuran antara jeruk nipis dan jeruk Pontianak. Inkubasi dilakukan pada suhu $37^{\circ} \mathrm{C}$ dan $50^{\circ} \mathrm{C}$. Pada suhu $37^{\circ} \mathrm{C}$ diperoleh 6 isolat yang tumbuh, dan 4 isolat yang tumbuh pada suhu $50^{\circ} \mathrm{C}$.

2. isolat 1 , isolat 4 dan isolat 9 optimum pada $\mathrm{pH} 4,0$, optimum suhu $50^{\circ} \mathrm{C}$. Ketiga isolat stabil pada $\mathrm{pH} 3,0-5,0$ dan pada suhu $30-50^{0} \mathrm{C}$. Nilai $\mathrm{K}_{\mathrm{m}}$ enzim isolat1, isolat 4 dan isolat 9 berturut-turut yaitu $0,022 \mathrm{mg} / \mathrm{ml} ; 0,009 \mathrm{mg} / \mathrm{ml} ; 0,017 \mathrm{mg} / \mathrm{ml}$. Nilai $\mathrm{V}_{\text {maks }}$ enzim isolat 1 , isolat 4 dan isolat 9 berturut-turut yaitu $0,041 \mathrm{U} / \mathrm{ml}$; $0,036 \mathrm{U} / \mathrm{ml} ; 0,039 \mathrm{U} / \mathrm{ml}$.

3. Ketiga isolat enzim mampu menurunkan viskositas, meningkatkan nilai tranmitansi atau kecerahan jus lemon dan meningkatkan nilai total padatan terlarut pada jus lemon dan pektin cair $1 \%$.

\section{DAFTAR PUSTAKA}

Arthey, D and P.R. Ashurst. 2001. Fruit Processing Nutritition Products and Quality Management, Second Edition. AM Aspen Publication. Maryland. p. 86148

Baker,R. A. 1997. Reassessment of Some Fruit and Vegetable Pectin Levels. Journal Of Food Science Volume 62, No. 2, 1997

Banik, S and S.N.Ghost. 2008. Pectinolytic Activity of Microorganisms in Piling of Jute. Indian journal of Fibre \& Textile Research Vo.33, June 2008,pp. 151-156.

Barense, R.I., M.A. Chellegati., M.J.V. Fonseca and S. Said. 2001. Partial Purification and Characterization of Exoplygalacturonase II and III of 
Braz.J.Microbiology. 32 (4) : 5-8

Benson, H. J. 2002. Microbiological Applications Laboratory Manual in General Microbiology. Eight Edition. Mc Graw Hill. Boston.

Fonseca, M, J. V and S. Said. 1994. The Pectinase Produced by Tubercularia vulgaris in Submerged Culture Using Pectin or Orange Pulp Pellets as Inducer. J. Appl. Microbiol. Biotechnol. Brazil.

Hadieotomo, R. S. 1990. Mikrobiologi Dasar dalam Praktek Teknik Dasar dan Prosedur Laboratorium. PT. Gramedia. Jakarta.

Noer, H. 2008. Pectinase: Small, but Important. http://foodreview.biz. Diakses pada tanggal 5 Januari 2013 pukul 10.00 WIB.

Ordonez, R. G., J. Morlon-Guyot, S. Casparian and J. P. Guyot. 1998. Occurrence of a Thermoacidophilic Cell-bound Exo-Pectinase in Alicyclobacillus acidocaldarius. Folia Microbiology. 43 (6). Mexico.

Putra, Ganda G.N. 2009. Penentuan Kinetika Enzim Poligalakturonase (PG) Endogenous dari Pulp Biji Kakao. Jurnal Biologi XIII (1) : $21-24$

Salvador, L.D., T. Singanuma., K. Kitahara., Y. Fukusage and H. Tanoue. 2002. Degradation of Cell Wall Materials from Sweet Potato, Cassava and Potato by A Bacterial Protopectinase and Terminal Sugar Analysis of The Resulting Solubilized Products, Journal of Bioscience and Bioengineering. 93 (1) : 64-72

Sierio, C. 2012. Microbial Pectic Enzymes in the Food and Wine Industry. Food Industrial Processes - Methods and Equipment 